\title{
Assessing the factors affecting the development of rural entrepreneurship: A case study of villages in Torbat-e Heydarieh, Kadkan district
}

\section{Evaluación de los factores que afectan el desarrollo del espíritu empresarial rural: un estudio de caso de pueblos en Torbat-e Heydarieh, distrito de Kadkan}

\author{
Mostafa Abbasi \\ PhD Student, Department of Geography and Rural Planning, Mashhad Branch, Islamic Azad \\ University, Mashhad, Iran \\ ORCID: https://orcid.org/0000-0001-6045-6323 \\ Hamid Jafari \\ Department of Geography, Mashhad Branch, Islamic Azad University, Mashhad, Iran \\ ORCID: https://orcid.org/0000-0002-2007-562X \\ Katayoun Alizadeh \\ Department of Geography, Mashhad Branch, Islamic Azad University, Mashhad, Iran \\ ORCID: https://orcid.org/0000-0001-7875-0977
}

Received 02-08-20 Revised 04-10-20

*Correspondence

Email: hamidjafari@yahoo.com
Accepted 01-11-21 On line 01-17-21

Cite as:

Abbasi, M., Jafari, H., \& Alizadeh, K. (2021). Assessing the factors affecting the development of rural entrepreneurship: A case study of villages in Torbat-e Heydarieh, Kadkan district. Propósitos y Representaciones, 9 (SPE1), e874. Doi: http://dx.doi.org/10.20511/pyr2021.v9nSPE1.874 


\section{Summary}

Entrepreneurship is one of the most important tools for planning and achieving the development of rural communities. Today, due to the problems in these communities, attention and emphasis on rural entrepreneurship is very important; because entrepreneurship can with creation an effective role in improving the economic and living conditions of villages by creating new employment and income opportunities. This article has been written with the aim of evaluating the factors affecting the development of rural entrepreneurship in a case study of villages in Torbat-e Heydarieh, Kadkan district. The research method was descriptive-analytical and the data collection method was library and field. One-sample t-test with principal component analysis was used to analyze the data. The statistical population of the study was the villagers of Kadkan district of Torbat-e Heydarieh, from which 240 people were selected as a sample and they were asked to complete a questionnaire. To assess the validity of the questionnaire, the content and face validity technique was used with the judgment of experts on research questions. The reliability of the research instrument was determined using Cronbach's alpha coefficient, which is above 0.75 for all dimensions and indicates the desirable capability of the questionnaire. The results showed that among the factors affecting entrepreneurship, the economic factor is the most influential factor in the study area. The results also showed that rural entrepreneurship is one of the suitable fields for creating employment in agricultural and non-agricultural sectors and one of the important factors in achieving sustainable development in rural areas.

Keywords: Entrepreneurship, Development, Village, Torbat Heydariyeh, Kodkan

\section{Resumen}

El espíritu empresarial es una de las herramientas más importantes para planificar y lograr el desarrollo de las comunidades rurales. Hoy, debido a los problemas en estas comunidades, la atención y énfasis en el emprendimiento rural es muy importante; porque el espíritu empresarial puede, con la creación, desempeñar un papel eficaz en la mejora de las condiciones económicas y de vida de las aldeas mediante la creación de nuevas oportunidades de empleo e ingresos. Este artículo ha sido escrito con el objetivo de evaluar los factores que afectan el desarrollo del emprendimiento rural en un estudio de caso de aldeas en Torbat-e Heydarieh, distrito de Kadkan. El método de investigación fue descriptivo-analítico y el método de recolección de datos fue biblioteca y campo. Se utilizó la prueba t de una muestra con análisis de componentes principales para analizar los datos. La población estadística del estudio fueron los aldeanos del distrito de Kadkan de Torbat-e Heydarieh, de los cuales se seleccionaron 240 personas como muestra y se les pidió que completaran un cuestionario. Para evaluar la validez del cuestionario se utilizó la técnica de validez de contenido y facial con el juicio de expertos en preguntas de investigación. La confiabilidad del instrumento de investigación se determinó mediante el coeficiente alfa de Cronbach, que está por encima de 0,75 para todas las dimensiones e indica la capacidad deseable del cuestionario. Los resultados mostraron que entre los factores que afectan el emprendimiento, el factor económico es el factor más influyente en el área de estudio. Los resultados también mostraron que el emprendimiento rural es uno de los campos adecuados para la creación de empleo en los sectores agrícola y no agrícola y uno de los factores importantes para lograr el desarrollo sostenible en las zonas rurales.

Palabras clave: Emprendimiento, Desarrollo, Pueblo, Torbat Heydariyeh, Kodkan 


\section{Introduction}

The village, which is the oldest form of human settlements, is one of the oldest forms of human life. Villages have traditionally played a key role in the prosperity of societies and civilizations and due to the numerous roles in the national development process, especially in the field of food supply, their growth and development is of great importance and necessity (Hosseini, 2011: 63).

It has been an urban area whose main cause is economic issues, especially access to employment. This has caused many problems such as marginalization, reduced quality of life, lack of employment and increased crime in cities; On the other hand, the reduced in the growth of the agricultural sector in rural areas and the reduction of employment by $23.4 \%$, shows the fact that in the future, agricultural development alone cannot guarantee economic growth in the countryside and eradicate poverty; Therefore, it is necessary to pay attention to other sectors along with the agricultural sector (Najafi Kani et al., 2015: 37).

\section{Rural and Rural Entrepreneurship}

For more than a century, researchers, sociologists, economists, geographers, government agencies, and immersed individuals have try to define "rural" more accurately using social, economic, and environmental components. There is a cultural hierarchy that considers urbanization as a positive feature and rurality as a negative one. This hierarchy is not culturally valid in many ways, because it is very easy to simply turn it into "urban - bad, rural - good". (Ritzer, 2007: 24).

Rurality is a controversial and complex concept, for example Dobson (2005) defines rural areas in the United States with differences in economics, values, environment, and climate. What can be concluded from his definition is that economics represents the occupation of agriculture and values that refer to issues such as religion and traditions of self-sufficiency and self-sufficiency, the environment, including unique and beautiful landscapes, and the large population of animals and livestock, and is covered by trees and family farms. Finally, it also shows that the atmosphere of a quiet life is a safe and healthy place to raise children. Another major work is about the countryside (Klok, 2006: 51). Inquiry; He identifies three important theoretical frameworks that have been influential in constructing rural conceptualization. The first case can be considered as practical rural concepts. In this context, a village can be defined in terms of areas under which they dominate agriculture and forestry, land use, includes smaller settlements from the bottom and residents and create a way of life that is characterized by respect for the environment and broad perspectives. A recent national program in Iran aimed at lending $4 \%$ interest rate to so-called rural entrepreneurs is a clear example of the practical meaning of rural, on the one hand, and the concept of supply of entrepreneurship (Thornton, 2011: 35).

Our study area is Kadkan section, one of the rural sections of Torbat Heydariyeh city in Khorasan Razavi province, In 2016, this region has a population of 12805 people (6438 men and 6367 women) with 3932 families and the two villages of Kadkan and Raqijeh with a population of 5941 and 3145, respectively, and has 17 villages and 16 inhabited villages. (Statistics Center of Iran, 2018).

In this study, we seek to answer the following questions, which are:

1. What are the factors affecting the development of rural entrepreneurship in the study area?

2. What factors have the greatest effect on entrepreneurship in the studied villages? 


\section{The need for entrepreneurship and its role in rural areas}

Entrepreneurship is one of the effective factors in rural development; because it can play an effective role in improving the economic and living conditions of villages by creating new employment and income opportunities; Therefore, measuring the entrepreneurship of the villagers and trying to develop and strengthen it in the process of rural development by providing its initial grounds is of particular importance. Due to special ecological and socioeconomic conditions, rural areas face many and various problems, which poverty and deprivation are the most important (Rezvani and Najarzadeh, 2008: 161). According to Reagan (2002: 23), rural entrepreneurship provides employment opportunities, increases income and wealth creation, improves the quality of life and helps local people to participate in the economy (Heritot, 2002: 19). Considering entrepreneurship as a model of economic development, rural development is defined as the process of encouraging, assisting and providing managerial and technical assistance to rural entrepreneurs, transportation and rural communication and information services, natural resource management and the like; Therefore, the development of rural entrepreneurship has the potential to diversify and increase agricultural and nonagricultural production of rural people and, consequently, increase income, and provides good opportunities to reduce livelihood risk and increase sustainable food security in rural areas and can be a good ground for Creating employment in agricultural and non-agricultural sectors (dabson \& other, 2003: 11).

\section{Research history}

Although entrepreneurial activities have traditionally and experimentally existed in different societies since the beginning of creation; But dealing with it in terms of scientific frameworks and methodological models has been considered by thinkers in recent decades. (Bouzarjomehri et al., 2014: 452).

The following table lists some of the research that has been done in this area.

\section{Table 1}

A summary of studies conducted in the field of rural entrepreneurship

\begin{tabular}{|c|c|c|c|}
\hline researcher & Year & subject & Results \\
\hline Rezvani et al & 1999 & $\begin{array}{c}\text { Study and analysis of } \\
\text { rural } \\
\text { entrepreneurship in } \\
\text { the process of rural } \\
\text { development }\end{array}$ & $\begin{array}{c}\text { Attracting young, specialized and skilled } \\
\text { manpower in rural areas and agricultural } \\
\text { activities The main strategy to create and } \\
\text { strengthen entrepreneurship in these areas for } \\
\text { sustainable development }\end{array}$ \\
\hline $\begin{array}{c}\text { Rokanuddin } \\
\text { Eftekhari et al }\end{array}$ & 2010 & $\begin{array}{c}\text { Agricultural } \\
\text { Entrepreneurship } \\
\text { Development } \\
\text { Strategies in Rural } \\
\text { Areas: A Case Study } \\
\text { of Khodabandeh } \\
\text { County Villages }\end{array}$ & $\begin{array}{c}\text { Capacities and capacities above the region, } \\
\text { the threshold of innovation and creativity in } \\
\text { the agricultural sector of rural areas need to be } \\
\text { reviewed and appropriate policies to remove } \\
\text { restrictions }\end{array}$ \\
\hline
\end{tabular}




\begin{tabular}{|c|c|c|c|}
\hline $\begin{array}{c}\text { Faraji Sabkbar } \\
\text { et al }\end{array}$ & 2011 & $\begin{array}{l}\text { Prioritization of } \\
\text { Entrepreneurship } \\
\text { Development in } \\
\text { Rural Areas Using } \\
\text { Prometric Technique } \\
\text { Case Study of } \\
\text { Suburban Rural } \\
\text { District of } \\
\text { Khodabandeh } \\
\text { County, Zanjan } \\
\text { Province }\end{array}$ & $\begin{array}{l}\text { Rural entrepreneurship is a new solution in } \\
\text { development theories for empowerment and } \\
\text { capacity building in rural areas with the aim } \\
\text { of reducing the gap between urban and rural } \\
\text { areas, creating economic, social, } \\
\text { environmental and institutional equality. }\end{array}$ \\
\hline Alidoost et al & 2012 & $\begin{array}{l}\text { Prioritization of } \\
\text { barriers to } \\
\text { entrepreneurship } \\
\text { development of rural } \\
\text { women in Garmsar } \\
\text { city }\end{array}$ & $\begin{array}{c}\text { Economic and educational barriers are the } \\
\text { most important obstacles in the development } \\
\text { of entrepreneurship of this segment of society, } \\
\text { respectively }\end{array}$ \\
\hline Behmand & 2015 & $\begin{array}{l}\text { Investigating the role } \\
\text { of rural tourism in the } \\
\text { development of rural } \\
\text { women } \\
\text { entrepreneurship in } \\
\text { Buchan city }\end{array}$ & $\begin{array}{l}\text { In the not-so-distant past, rural women } \\
\text { worked alongside men in many jobs. } \\
\text { However, due to social, economic and cultural } \\
\text { developments, the role of women in rural } \\
\text { activities has been greatly reduced in recent } \\
\text { years. This has caused many social and } \\
\text { economic problems to the villages. }\end{array}$ \\
\hline Anbarloo et al & 2016 & $\begin{array}{l}\text { Investigating the role } \\
\text { of women } \\
\text { entrepreneurship in } \\
\text { the economic } \\
\text { development of } \\
\text { human settlements }\end{array}$ & $\begin{array}{l}\text { It is necessary to pay attention to women's } \\
\text { entrepreneurship and empowerment of } \\
\text { women for their entrepreneurship and their } \\
\text { decisive role in sustainable development are } \\
\text { among the issues that should be considered in } \\
\text { theory and application. }\end{array}$ \\
\hline $\begin{array}{l}\text { Healing Nia et } \\
\text { al }\end{array}$ & 2016 & $\begin{array}{l}\text { Investigating the role } \\
\text { of entrepreneurship } \\
\text { process in sustainable } \\
\text { rural development } \\
\text { with emphasis on } \\
\text { social development }\end{array}$ & $\begin{array}{l}\text { One of the dynamic tools in the development } \\
\text { process is the entrepreneurship tool that can } \\
\text { provide the conditions for the development } \\
\text { process in its various dimensions, especially } \\
\text { in the social dimension. Social development is } \\
\text { one of the important factors in achieving } \\
\text { sustainable rural development, which } \\
\text { improves the quality of life of villagers, social } \\
\text { justice, collective participation and rural trust } \\
\text { and security. }\end{array}$ \\
\hline Khateri et al & 2016 & $\begin{array}{l}\text { Investigating the role } \\
\text { of rural handicrafts } \\
\text { and tourism for the } \\
\text { development of rural } \\
\text { women } \\
\text { entrepreneurship }\end{array}$ & $\begin{array}{l}\text { Given that about half of the country's } \\
\text { population and a significant portion of the } \\
\text { economically active population are women } \\
\text { and their proportion in the educated } \\
\text { community is still increasing, but have not yet } \\
\text { gained a decent share in the national } \\
\text { economy. However, women entrepreneurs in } \\
\text { their entrepreneurial path have been able to } \\
\text { achieve successes that can have a tremendous } \\
\text { effect on the economic, social and political }\end{array}$ \\
\hline
\end{tabular}




\begin{tabular}{|c|c|c|c|}
\hline & & & arenas of the country. \\
\hline $\begin{array}{c}\text { Ramezanzadeh } \\
\text { Lesboui et al }\end{array}$ & 2016 & $\begin{array}{l}\text { Analysis of the } \\
\text { Relationship between } \\
\text { Awareness and } \\
\text { Entrepreneurship of } \\
\text { Local Communities } \\
\text { in Tourism (Case } \\
\text { Study: Rural Areas of } \\
\text { Mianband County, } \\
\text { Noor County) }\end{array}$ & $\begin{array}{l}\text { Entrepreneurship is growing rapidly in } \\
\text { important economic sectors, and one of these } \\
\text { areas is tourism. In order to develop } \\
\text { entrepreneurial activities in the rural tourism } \\
\text { sector, various factors such as environmental } \\
\text { capacities with emphasis on the tourism } \\
\text { sector, individual, psychological factors, etc. } \\
\text { are influential. }\end{array}$ \\
\hline Narrative & 2016 & $\begin{array}{l}\text { Investigating the } \\
\text { challenges of } \\
\text { entrepreneurship in } \\
\text { the village }\end{array}$ & $\begin{array}{l}\text { Nevertheless, the rural areas of the country } \\
\text { have good capabilities and potentials to help } \\
\text { the development of the country. In this regard, } \\
\text { more attention to rural entrepreneurship is a } \\
\text { necessity. On the other hand, we know that } \\
\text { entrepreneurship is a key factor and the key to } \\
\text { the survival of organizations and is a source } \\
\text { of employment and growth and development }\end{array}$ \\
\hline $\begin{array}{c}\text { Raffles Bar et } \\
\text { al }\end{array}$ & 1998 & $\begin{array}{l}\text { Entrepreneurship and } \\
\text { Rural Industry } \\
\text { Comparison of Urban } \\
\text { and Rural Patterns, A } \\
\text { Case Study of Israel } \\
\text { (Zionist Regime) }\end{array}$ & $\begin{array}{l}\text { According to local characteristics, relative } \\
\text { industrial development can be created in rural } \\
\text { areas by attracting local and indigenous } \\
\text { people and using this power. }\end{array}$ \\
\hline Louvre et al & 2012 & $\begin{array}{l}\text { Modern } \\
\text { entrepreneurship and } \\
\text { agriculture in rural } \\
\text { areas A case study of } \\
\text { the Netherlands }\end{array}$ & $\begin{array}{l}\text { Age has an effect on agricultural employment } \\
\text { in the region and more active knowledge } \\
\text { infrastructure, management, systems and } \\
\text { chains are the requirements of rural } \\
\text { entrepreneurship. }\end{array}$ \\
\hline Zaltin et al & 2013 & $\begin{array}{l}\text { Rural } \\
\text { Entrepreneurship A } \\
\text { Case Study of the } \\
\text { United States }\end{array}$ & $\begin{array}{l}\text { Access to resources, need for information, } \\
\text { skilled labor, technology and capital are } \\
\text { among the problems of villages in the } \\
\text { direction of entrepreneurship. }\end{array}$ \\
\hline Kazabov & 2014 & $\begin{array}{l}\text { When an initiative } \\
\text { promises more than } \\
\text { that }\end{array}$ & $\begin{array}{l}\text { A Multi-Player Perspective on Rural } \\
\text { Entrepreneurship Problems and Failure in } \\
\text { Thailand National governments invest in } \\
\text { initiatives aimed at promoting rural } \\
\text { entrepreneurship, which contributes to } \\
\text { competition and employment. }\end{array}$ \\
\hline
\end{tabular}




\begin{tabular}{|c|c|c|c|}
\hline Otop & 2015 & $\begin{array}{c}\text { When Rural } \\
\text { Entrepreneurship } \\
\text { Marketing Does Not } \\
\text { Work: A Case of } \\
\text { OTOP Failure in } \\
\text { Thailand }\end{array}$ & $\begin{array}{l}\text { The entry of corporate resources into } \\
\text { competitive advantage has generally been } \\
\text { theorized and empirically examined in the } \\
\text { context of large corporations. Metaphysics } \\
\text { discusses resources in small companies and } \\
\text { entrepreneurial investments. However, these } \\
\text { issues require empirical testing, as } \\
\text { entrepreneurship plays an important role in } \\
\text { economic development and contributes to } \\
\text { rural communities. }\end{array}$ \\
\hline Madan et al & 2015 & $\begin{array}{l}\text { Rapid growth rates in } \\
\text { India and other Asian } \\
\text { countries }\end{array}$ & $\begin{array}{l}\text { Entrepreneurship has significantly reduced the } \\
\text { incidence of poverty, as well as increased } \\
\text { inequality in local sub-areas, especially in } \\
\text { rural and urban areas, and between skilled and } \\
\text { inefficient workers. }\end{array}$ \\
\hline Kashik et al & 2016 & $\begin{array}{l}\text { How to Teach } \\
\text { Human Rights and } \\
\text { Entrepreneurship in } \\
\text { Rural Areas A Case } \\
\text { Study of Rural } \\
\text { Women in India }\end{array}$ & $\begin{array}{l}\text { Promoting entrepreneurship and educating } \\
\text { rural women has been effective through } \\
\text { educating women }\end{array}$ \\
\hline Dobson & 2016 & $\begin{array}{l}\text { Supporting rural } \\
\text { entrepreneurship }\end{array}$ & $\begin{array}{l}\text { Instead of trying to get an overview of any } \\
\text { general program that may have a direct or } \\
\text { indirect impact on entrepreneurship that } \\
\text { focuses on the main topic. }\end{array}$ \\
\hline Sharpley & 2016 & $\begin{array}{l}\text { Establishing a link } \\
\text { between } \\
\text { entrepreneurship, } \\
\text { capital and poverty } \\
\text { reduction in rural } \\
\text { Ghana }\end{array}$ & $\begin{array}{l}\text { The strategy overcomes the fact that } \\
\text { entrepreneurial conditions in rural areas are } \\
\text { substantially based on other factors, especially } \\
\text { those related to capital or infrastructure built. } \\
\text { This article argues that construction capital } \\
\text { can reduce rural entrepreneurship or thus } \\
\text { alleviate poverty. }\end{array}$ \\
\hline Mahmood & 2016 & $\begin{array}{l}\text { Barriers to Rural } \\
\text { Entrepreneurship } \\
\text { Development and } \\
\text { Focus, Focusing on } \\
\text { Entrepreneurs' } \\
\text { Experiences of } \\
\text { Keeping Them } \\
\text { Starting a Micro- } \\
\text { Business }\end{array}$ & $\begin{array}{l}\text { Religious, socio-economic and structural } \\
\text { forces play an important role in suppressing } \\
\text { social and cultural capital in rural Pakistan } \\
\text { and explain the low level of entrepreneurship } \\
\text { in these areas. Social and cultural capital } \\
\text { requires special social and economic } \\
\text { conditions for entrepreneurial growth }\end{array}$ \\
\hline Jinti et al & 2017 & $\begin{array}{l}\text { The role of social } \\
\text { entrepreneurship } \\
\text { among farmers A } \\
\text { case study of Kenyan } \\
\text { farmers }\end{array}$ & $\begin{array}{l}\text { Entrepreneurial success is partly related to the } \\
\text { individual and the leadership institution, but } \\
\text { familiarity with culture and group learning } \\
\text { has also been one of the successes in the } \\
\text { entrepreneurship development program. }\end{array}$ \\
\hline Kayona & 2017 & $\begin{array}{l}\text { Entrepreneurship and } \\
\text { rural transformation }\end{array}$ & $\begin{array}{l}\text { While highlighting the factors that increase } \\
\text { success as well as those that hinder } \\
\text { development, the study found that the learner }\end{array}$ \\
\hline
\end{tabular}




\begin{tabular}{|c|c|c|c|}
\hline Masumola & 2017 & $\begin{array}{c}\text { in the role of learning } \\
\text { entrepreneurship in } \\
\text { Tanzania: Why do } \\
\text { small and medium- } \\
\text { sized enterprises not } \\
\text { create productive } \\
\text { value in the furniture } \\
\text { industry? }\end{array}$ & $\begin{array}{c}\text { contributes significantly to social } \\
\text { transformation through rural entrepreneurship. } \\
\text { Lack of financial capital, lack of proper } \\
\text { technology, lack of market, lack of raw } \\
\text { materials, lack of skills and lack of } \\
\text { commitment, hinder the ability of rural MSE } \\
\text { to create value. Legal concerns, suppliers, } \\
\text { customers, competitors, intermediaries, and } \\
\text { transportation issues limit rural MSE's ability } \\
\text { to create value }\end{array}$ \\
\hline Jazip et al & 2018 & $\begin{array}{c}\text { The Role of Social } \\
\text { Capital in Women } \\
\text { Entrepreneurship in } \\
\text { Rural Areas A Case } \\
\text { Study of Vietnam }\end{array}$ & $\begin{array}{c}\text { Existence of social capital increases women's } \\
\text { desire from family entrepreneurship to } \\
\text { organizational entrepreneurs and access and } \\
\text { distance to the market also affect it. }\end{array}$ \\
\hline
\end{tabular}

\section{Methodology}

The present research is applied in terms of purpose and descriptive-analytical in terms of method. Field and non-field methods were used to collect the required information, while in order to complete the questionnaires, the survey method was used and the questionnaires were distributed and collected within a month. 240 of them were selected as a sample. According to the research questions and the characteristics of the people, a questionnaire in the form of 15 items was prepared and completed by 240 people as a sample. To assess the validity of the questionnaire, the method and technique of content and face validity with the judgment of experts (university professor and statistician) on the research questions were used.

\section{Table 2}

Cronbach's alpha of the dimensions examined in the questionnaire

\begin{tabular}{|c|c|c|c|c|c|c|c|c|}
\hline Indicator & $\begin{array}{c}\text { Numbe } \\
\mathrm{r}\end{array}$ & $\begin{array}{c}\text { Averag } \\
\mathrm{e}\end{array}$ & $\begin{array}{c}\text { Standard } \\
\text { deviatio } \\
\mathrm{n}\end{array}$ & $\begin{array}{c}\text { Varianc } \\
\mathrm{e}\end{array}$ & $\begin{array}{c}\text { Chole } \\
\text { gi }\end{array}$ & $\begin{array}{c}\text { Elong } \\
\text { ation }\end{array}$ & $\begin{array}{c}\text { The } \\
\text { least }\end{array}$ & $\begin{array}{c}\text { The } \\
\text { most }\end{array}$ \\
\hline Consult & 50 & $68 / 3$ & $74 / 0$ & $77 / 0$ & $-64 / 0$ & $54 / 0$ & $33 / 1$ & $00 / 5$ \\
\hline Education & 50 & $78 / 3$ & $71 / 0$ & $82 / 0$ & $-81 / 0$ & $16 / 0$ & $50 / 1$ & $00 / 5$ \\
\hline personal experience & 50 & $44 / 3$ & $78 / 0$ & $70 / 0$ & $-55 / 0$ & $-04 / 0$ & $20 / 1$ & $00 / 5$ \\
\hline $\begin{array}{c}\text { Individual } \\
\text { characteristics }\end{array}$ & 50 & $63 / 3$ & $64 / 0$ & $63 / 0$ & $-89 / 0$ & $90 / 0$ & $46 / 1$ & $88 / 4$ \\
\hline Marketing & 50 & $40 / 3$ & $88 / 0$ & $91 / 0$ & $-85 / 0$ & $72 / 0$ & $00 / 1$ & $00 / 5$ \\
\hline Development & 50 & $39 / 3$ & $72 / 0$ & $80 / 0$ & $-84 / 0$ & $68 / 1$ & $00 / 1$ & $00 / 5$ \\
\hline Capital & 50 & $71 / 3$ & $78 / 0$ & $64 / 0$ & $-60 / 0$ & $02 / 1$ & $00 / 1$ & $00 / 5$ \\
\hline
\end{tabular}




\begin{tabular}{|c|c|c|c|c|c|c|c|c|}
\hline $\begin{array}{c}\text { Marketing and } \\
\text { development and } \\
\text { capital }\end{array}$ & 50 & $501 / 3$ & $57 / 0$ & $72 / 0$ & $-22 / 1$ & $23 / 3$ & $00 / 1$ & $83 / 4$ \\
\hline
\end{tabular}

According to Table 2, because the Cronbach's alpha value is higher than $70 \%$, it shows that the items of the research tool have a high internal correlation and the research tool has good reliability. The collected data were processed using SPSS software and one-sample T method. A method is used to calculate the internal consistency of a measuring instrument that measures different properties. Cronbach's alpha coefficient is between 0 and 1 . The number 1 shows the maximum correlation and the number 0 shows the lowest correlation. The closer the percentage is to $100 \%$, the questionnaire is more reliable. We have to say that an alpha coefficient of less than $60 \%$ is usually considered weak, an amplitude of $70 \%$ is acceptable and above $80 \%$ is considered good, but the closer the coefficient of confidence is to number one, the better. The overall Cronbach's alpha value in the questionnaire was 0.758 , which is finally acceptable considering the above, which indicates the appropriate reliability of the research questionnaire. Based on the prototype of 50, the Cronbach's alpha level of the questionnaire for its dimensions is listed in the table below.

\section{Table 3}

Dimensions of research indicators

\begin{tabular}{|c|c|c|}
\hline \multicolumn{2}{|c|}{ Components } & Indicators and Reagents \\
\hline $\begin{array}{l}\text { Potentials and } \\
\text { capacities for } \\
\text { developing } \\
\text { entrepreneurship } \\
\text { and rural } \\
\text { employment }\end{array}$ & $\begin{array}{l}\text { Potentials and } \\
\text { capacities for } \\
\text { developing } \\
\text { entrepreneurship } \\
\text { and rural } \\
\text { employment }\end{array}$ & $\begin{array}{l}\text { Consulting, persevering and standing up to problems, } \\
\text { familiarity with business rules, business experience, rural } \\
\text { capital status, self-confidence, participatory spirit, } \\
\text { responsibility, literacy }\end{array}$ \\
\hline $\begin{array}{c}\text { Individual } \\
\text { characteristics }\end{array}$ & $\begin{array}{c}\text { Individual } \\
\text { characteristics }\end{array}$ & $\begin{array}{l}\text { Allocating subsidies to entrepreneurial activities, } \\
\text { compiling a document on national entrepreneurship } \\
\text { development, encouraging local investors, the existence of } \\
\text { property and credit institutions, helping the villagers to } \\
\text { allocate capital by the government, buying the products of } \\
\text { the villagers, developing the wealth of the villagers }\end{array}$ \\
\hline
\end{tabular}

\section{General characteristics of respondents}

The distribution of respondents according to age groups in the present study was as follows: $26.6 \%$ in the age groups 20 to 29 and $40 \%$ in the age group 30-39, 20\% 40-49 and $13.4 \% 50$ years and above, their literacy status shows. $75.41 \%$ of them were literate and $24.59 \%$ were illiterate, their literacy status shows that 41.25 percent of people are unemployed and 58.57 percent of people are employed. Their entrepreneurial background shows that 23.75 percent of respondents have no entrepreneurial background and 76.25 people have entrepreneurial background.

\section{Questionnaire indicators}




\section{Individual features}

Table (3) has 2 indicators that according to the respondents, "Education" index with an average weight of 3.78 first rank, "Consultation" with an average weight of 3.68 second rank and "Personal experience" with an average weight of 3.44 ranks have earned the third. In describing the individual health branch, it can be said that personal characteristics are the main capital of entrepreneurs; as people are always looking to take advantage of opportunities around them to create something new or change it and turn threats into opportunities and use them for the benefit of themselves and society. Entrepreneurs see failure as a good opportunity to win and golden notes that can be a way to achieve all their goals and aspirations.

Table 4

Variance and standard deviation of variables Individual characteristics

\begin{tabular}{|c|c|c|c|c|c|c|c|c|c|}
\hline Indicator & $\begin{array}{c}\text { Numbe } \\
\mathrm{r}\end{array}$ & $\begin{array}{c}\text { Averag } \\
\mathrm{e}\end{array}$ & $\begin{array}{c}\text { Standar } \\
\mathrm{d} \\
\mathrm{deviatio} \\
\mathrm{n}\end{array}$ & $\begin{array}{c}\text { Varianc } \\
\mathrm{e}\end{array}$ & $\begin{array}{c}\text { Chole } \\
\mathrm{gi}\end{array}$ & $\begin{array}{c}\text { Elongatio } \\
\mathrm{n}\end{array}$ & $\begin{array}{c}\text { The } \\
\text { leas } \\
\mathrm{t}\end{array}$ & $\begin{array}{c}\text { The } \\
\text { mos } \\
\mathrm{t}\end{array}$ & $\begin{array}{c}\text { Ran } \\
\mathrm{k}\end{array}$ \\
\hline Consult & 50 & $68 / 3$ & $74 / 0$ & $77 / 0$ & $-64 / 0$ & $54 / 0$ & $\begin{array}{c}33 / \\
1\end{array}$ & $\begin{array}{c}00 / \\
5\end{array}$ & 2 \\
\hline Education & 50 & $78 / 3$ & $71 / 0$ & $82 / 0$ & $-81 / 0$ & $16 / 0$ & $\begin{array}{c}50 / \\
1\end{array}$ & $\begin{array}{c}00 / \\
5\end{array}$ & 1 \\
\hline $\begin{array}{c}\text { personal } \\
\text { experience }\end{array}$ & 50 & $44 / 3$ & $78 / 0$ & $70 / 0$ & $-55 / 0$ & $-04 / 0$ & $\begin{array}{c}20 / \\
1\end{array}$ & $\begin{array}{c}00 / \\
5\end{array}$ & 3 \\
\hline $\begin{array}{c}\text { Individual } \\
\text { characteristi } \\
\text { cs }\end{array}$ & 50 & $63 / 3$ & $64 / 0$ & $63 / 0$ & $-89 / 0$ & $90 / 0$ & $46 /$ & $88 /$ & $*$ \\
4 & & & & & & & \\
\hline
\end{tabular}

\section{Marketing and development and capital}

In table number (3), which is related to marketing, development and capital, based on the mentioned indicators and ranking, the "capital" index with a weight average of 3.71 has the first rank, the second index, which is "marketing", has an average A weight of 3.40 is in the next rank and the last rank reaches the "Development" index with an average weight rank of 3.39, Based on this, it can be said that the respondents of capital consider the best indicator among other monetary indicators that basically no work and development is possible without capital and after that, you have to think about selling products and products to reach the final and ideal development.

\section{Table 5}

Variance and standard deviation of variables Marketing and Development and Capital 


\begin{tabular}{|l|l|l|l|l|l|l|l|l|l|}
\hline Indicator & $\begin{array}{l}\text { Numbe } \\
\mathrm{r}\end{array}$ & $\begin{array}{l}\text { Averag } \\
\mathrm{e}\end{array}$ & $\begin{array}{l}\text { Standard } \\
\text { deviation }\end{array}$ & $\begin{array}{l}\text { Vari } \\
\text { ance }\end{array}$ & $\begin{array}{l}\text { Choleg } \\
\mathrm{i}\end{array}$ & $\begin{array}{l}\text { Elongat } \\
\text { ion }\end{array}$ & $\begin{array}{l}\text { The } \\
\text { least }\end{array}$ & $\begin{array}{l}\text { The } \\
\text { most }\end{array}$ & $\begin{array}{l}\text { Ra } \\
\mathrm{nk}\end{array}$ \\
\hline Marketing & 50 & $40 / 3$ & $88 / 0$ & $91 / 0$ & $-85 / 0$ & $72 / 0$ & $00 / 1$ & $00 / 5$ & 2 \\
\hline Development & 50 & $39 / 3$ & $72 / 0$ & $80 / 0$ & $-84 / 0$ & $68 / 1$ & $00 / 1$ & $00 / 5$ & 3 \\
\hline Fund & 50 & $71 / 3$ & $78 / 0$ & $64 / 0$ & $-60 / 0$ & $02 / 1$ & $00 / 1$ & $00 / 5$ & 1 \\
\hline $\begin{array}{l}\text { Marketing, } \\
\text { Development } \\
\text { and Capital }\end{array}$ & 50 & $501 / 3$ & $57 / 0$ & $72 / 0$ & $-22 / 1$ & $23 / 3$ & $00 / 1$ & $83 / 4$ & $*$ \\
\hline
\end{tabular}

\section{Results}

\section{Testing hypotheses}

-There is a significant relationship between individual characteristics of villagers and entrepreneurship development. This hypothesis can be tested as a statistical hypothesis as follows.

H0: There is no significant relationship between individual characteristics of villagers and entrepreneurship development. (The average of the variable is not more than 3 ).

H1: There is a significant relationship between individual characteristics of villagers and entrepreneurship development. (The average of the variable is more than 3).

Based on t-test, the results of which are also listed in the table below:

\section{Table 6}

Results of comparing the mean effect of individual characteristics of villagers and entrepreneurship development with the number 3 by t-test

\begin{tabular}{|l|l|l|l|l|l|l|}
\hline Review & $\begin{array}{l}\text { Averag } \\
\mathrm{e}\end{array}$ & $\begin{array}{l}\text { Standard } \\
\text { deviatio } \\
\mathrm{n}\end{array}$ & $\begin{array}{l}\text { Statistic } \\
\mathrm{s} \mathrm{t}\end{array}$ & $\begin{array}{l}\text { Degrees of } \\
\text { freedom }\end{array}$ & $\begin{array}{l}\mathrm{p}- \\
\text { value }\end{array}$ & $\begin{array}{l}\text { The result of } \\
\text { the } \\
\text { hypothesis }\end{array}$ \\
\hline $\begin{array}{l}\text { The average } \\
\text { effect } \begin{array}{l}\text { ind of } \\
\text { individual } \\
\text { characteristics } \\
\text { of villagers and } \\
\text { entrepreneurshi } \\
\text { p development }\end{array}\end{array}$ & $635 / 3$ & $643 / 0$ & $428 / 11$ & 133 & $000 / 0$ & $\begin{array}{l}\text { Confirmatio } \\
\mathrm{n}\end{array}$ \\
\hline
\end{tabular}

It is observed that the p-value divided by 2 tests is less than 0.05 and the t-statistic is positive (11.428), so it can be said that the null hypothesis that the effect of individual characteristics of villagers and entrepreneurship development have no significant effect, becomes rejected, In other words, the average effect of individual characteristics of villagers and entrepreneurship development is higher than average, so it can be concluded that individual characteristics are 
effective in the development of rural entrepreneurship development, i.e. the first hypothesis is confirmed.

There is a significant relationship between marketing and entrepreneurship development.

H0: There is no significant relationship between marketing and entrepreneurship development. (The average of the variable is not more than 3 ).

H1: There is a significant relationship between marketing and entrepreneurship development. (The average of the variable is more than 3 ).

Based on t-test, the results of which are also listed in the table below:

\section{Table 7}

Results of comparing the mean effect of a significant relationship between marketing and rural entrepreneurship development with the number 3 by t-test

\begin{tabular}{|l|l|l|l|l|l|l|}
\hline Review & $\begin{array}{l}\text { Averag } \\
\mathrm{e}\end{array}$ & $\begin{array}{l}\text { Standard } \\
\text { deviatio } \\
\mathrm{n}\end{array}$ & $\begin{array}{l}\text { Statistic } \\
\mathrm{s} \mathrm{t}\end{array}$ & $\begin{array}{l}\text { Degrees of } \\
\text { freedom }\end{array}$ & $\begin{array}{l}\mathrm{p}- \\
\text { value }\end{array}$ & $\begin{array}{l}\text { The result of } \\
\text { the } \\
\text { hypothesis }\end{array}$ \\
\hline $\begin{array}{l}\text { The average } \\
\text { effect of a } \\
\text { significant } \\
\text { relationship } \\
\text { between } \\
\text { marketing and } \\
\text { rural } \\
\text { entrepreneurshi } \\
\text { p development }\end{array}$ & $3 / 501$ & $0 / 574$ & $10 / 087$ & 133 & $000 / 0$ & $\begin{array}{l}\text { Confirmatio } \\
\mathrm{n}\end{array}$ \\
\hline
\end{tabular}

It is observed that the p-value divided by 2 tests is less than 0.05 and the t-statistic is positive (10.087), so we can say that the null hypothesis that there is a significant relationship between marketing and rural entrepreneurship development has a significant effect, becomes rejected, In other words, the effect of a significant relationship between marketing and rural entrepreneurship development is more than average, so it can be concluded that there is a significant relationship between marketing and entrepreneurship development, i.e. the second hypothesis is confirmed.

\section{Conclusion}

Paying attention to private sector investment in rural areas;-

-Paying attention to the participation of local communities in rural development programs;

Teaching different skills to talented villagers;-

-Attention and emphasis on the indigenous knowledge of the villagers and the creation of rural industries by entrepreneurs with the aim of creating land to create employment in the villages and, consequently, prevent the migration of villagers to the cities; 
- Construction of suitable and wide access roads for the movement of trucks and creating suitable places for drivers who come and go on the road including accommodation and service complexes suitable for the region, which is sometimes seen in some areas; ensure security is fully pursued by setting up police stations and sometimes checkpoints in the area And the most important thing is to create suitable educational environments for the villagers who do not travel to neighboring villages to study and this does not make them want to migrate;

- Consulting with locals can be considered one of the biggest measures. Because this is how the personality of the people is respected and that these people compete for more cooperation in the development plan and so on; another point is that the residents of the area know better about the problems to be addressed; and this avoids spending money and the right facilities are built and used in the right place for the residents;

- It is necessary to prevent their migration by creating suitable job opportunities with appropriate income for rural people; to prevent the villages from being emptied and destroyed; this can be with government investment or the private sector in the region or long-term loans with low interest rates; that the villagers should be able to work with peace of mind and worry about heavy repayment; because agriculture does not have the same profit and the whole part of the crop may be lost every year due to the weather, pests and other problems of the agricultural sector;

The results of this study show that entrepreneurship with a positive effect on economic, social, institutional and cultural aspects, leads to strengthening national culture and identity, diversifying agricultural, industrial and rural services and maintaining the population with minimal damage to the rural environment; It reduces the migration of villagers to the cities and also provides employment, welfare and development in the village where they live; And according to the above, it may be possible to prevent the destruction of rural areas and the agricultural sector and the migration of villagers, which in turn has put double pressure on cities and the population of cities is increasing.

\section{References}

Audretsch, D. (2002). Entrepreneurship: a survey of the literature. London: Institute for Development Strategies.

Bouzarjomehri, K., Romiani, A., \&Ismaili, A. (2014). A Study of Factors Affecting Entrepreneurship Growth in Strengthening Rural Communities for Sustainable Development, National Conference on Sustainable Rural Development in the Sixth National Development Plan, Scientific Association of Geography and Rural Planning, University of Tehran.

Cloke, P. (2006). Conceptualizing rurality. In P. Cloke, T. Mardsen, \& P. H. Mooney Eds., Handbook of rural studies. London: Sage.

Dabson, B. (2005). Entrepreneurship as a real community and economic development strategy. Rural policy research institute \& truman school of public affairs. Columbia: University of Missouri.

Dabson, B., Malkin, J., Matthews, A., Pate, K., \& Stickle, S. (2003). Mapping Rural Entrepreneurship. Rural Development, 3(8), 123-113.

Farahani, H., Zakieh Rasoul Y., \& Zahra Sedghi, S. (2014). Factors Affecting Entrepreneurship Growth in Rural Areas Study: Jaber Ansar Village in Abdanan County, Space Economics and Rural Development, 3(9), 89-99. 
Hosseini, I. (2011). The role of entrepreneurship in the development of rural areas of Kaki section of Dashti province, Master's Degree in Geography and Rural Planning, Sistan and Baluchestan University.

Jeanette S., \& Martina, M. N. (2010). Social entrepreneurship among Kenyan farmers.International Journal of Intercultural Relation, 3(4), 7-13.

Najafi Kani, A.A., Mehdi, H \& Hadiseh, A. (2015). Assessing the status of entrepreneurial development in rural areas: South Astarabad district in Gorgan province, Quarterly Journal of Space Economics and Rural Development, 4(1), 78-88.

Reagan, B. (2002). Area Highgrowth Entrepreneurs Building the Rural Economy? Center for the Stud of Rural America, Kansas City, Mo: Federal Reserve bank of Kansas City.

Ritzer, G. (2007). Contemporary sociological theory and its classical roots. New York: McGraw-Hill University of Jyvaskyla.

Rokanuddin, E., Abdolreza, Mehdi, T., \& Hamdollah, S. (2009). Analysis of Dimensions and Factors Affecting the Development of Agricultural ntrepreneurship in Rural Areas Case Study: Villages of Khodabandeh County, Rural and Development Quarterly, 12(3), 414.

Shahraki, H., Movahedi, R., \& Yaghoubi Farani, A. (2016). From Arturo Escobar's development theory to Antony Giddens's structuration theory: A social constructionist analysis of rural entrepreneurship and multifunctional agriculture. International Journal of Agricultural Resources, Governance and Ecology, 12, 406-426.

Statistics Center of Iran. (2016). excerpt from the results of the General Population and Housing Census 2016.

Thornton, P. (1999). The sociology of entrepreneurship. Annual Review of the Social Sciences of Religion, 25, 19-46.

Vosooghi, M., \& Eemani, A. (2010). Ayande-ye Tose-ye Roosta'i va Chalesh-ha-ye Paydari future of rural development and sustainability challenges. Rural Development Journal, $12,23-45$. 